\title{
Development of resource-saving technology when mining ore bodies by blocks under rock pressure
}

\author{
Serhii Pysmenniy ${ }^{1, *}$, Natalya Shvager ${ }^{2}$, Oleksandr Shepel $^{1}$, Kostiantyn Kovbyk ${ }^{1}$, and Oleksandr Dolgikh ${ }^{3}$ \\ ${ }^{1}$ Kryvyi Rih National University, Department of Underground Mining of Mineral Deposit, 11 Vitalii Matusevych Str., Kryvyi Rih, \\ 50027, Ukraine \\ ${ }^{2}$ Kryvyi Rih National University, Department of labor protection and civil security, 11 Vitalii Matusevych Str., Kryvyi Rih, 50027, \\ Ukraine \\ ${ }^{3}$ Kryvyi Rih National University, Department of Mine Surveying, 11 Vitalii Matusevych Str., Kryvyi Rih, 50027, Ukraine
}

\begin{abstract}
The article aims to develop the resource-saving technology when mining steep ore bodies applying $250 \mathrm{~mm}$-diameter boreholes to break ore into the compressed environment. This will reduce dilution of the mined ore mass in conditions of rock pressure around blocks. When mining iron ore deposits of Kryvyi Rih basin, applied mining systems allow for creation of the compensatory space as the first stage. However, these stopes fail under rock pressure, this influencing negatively ore breaking and extraction. The degree of extraction can be increased through breaking ore mass into the compressed environment. The width of the ore layer to be broken onto the compressed environment is determined through industrial investigations. To enhance breaking conditions, it is suggested to apply boreholes of a larger diameter. However, there is no technique developed for determining thickness of the ore layer to be broken depending on the borehole diameter and the fragmentation factor. When applying $250 \mathrm{~mm}$ boreholes, increase of thickness of the layer to be broken from 2 to $10 \mathrm{~m}$ is found to cause compaction of the previously broken layer up to $3 \mathrm{~m}$ with the optimal ore fragmentation factor of 1.3-1.5 and 3-fold decrease of lumps yield. This results from the fact that drilling a $250 \mathrm{~mm}$ borehole to secure even provision of the massif with explosives reduces the line of the least resistance.
\end{abstract}

\section{Introduction}

Kryvyi Rih iron ore basin accounts for over 32.2 bn $t$ of iron ores with iron content in the massif of $24-65 \%$ that are mined by underground and open-pit methods. Iron ores with the useful component content of $60-65 \%$ are mined applying bulk-caving methods on the compensatory area or open stoping and further caving of enclosing rocks [1-4].

Underground mining of ore bodies is performed at the depths of 1220-1350 m. Geometric parameters of ore bodies are as follows: along the strike length is 800$1200 \mathrm{~m}$; thickness is $30-120 \mathrm{~m}$; dip angles are $45-85^{\circ}$ [5-7].

Mining operations are performed in the following order: the ore body is vertically divided into levels of 75-90 $\mathrm{m} \mathrm{high}$; it is mined along the strike from the center to its flanks or from the flanks to the center. Nevertheless, because preparation operations are behind schedule, mining enterprises do not keep to this order that results in concentration of stresses around the block and decreased ore extraction [8-10].

Works [11-15] suggest various options of mining systems enabling increase of extraction of ore mass from stope blocks. However, blocks fail under the influence of rock pressure when forming the compensatory area, thus causing increased mining costs and time.
To increase iron content in the muck, it is suggested to concentrate the mass at surface crushing and sizing plants. [16-18]. It should be considered that in terms of mineralogical composition there are 6-9 varieties of ore, each requiring special treatment. At present, there are developed and successfully implemented various automated complexes due to which the useful component content in ore mass increases by $3-6 \%$ (i.e. from $56 \%$ to $62 \%$ ) [19-21]. This updating trend is based on force impacts on the substance during disintegration in the activator but it does not consider processes connected with underground mining of the useful mineral [22-25]. Constantly improved software of the automated complexes indicates iron content in real time and is able to split ore mass flows by quality.

Nevertheless, all these measures inevitably result in increased mining costs (by 2-7\%), decreased annual output of the mine (by 10-20\%) and alienation of agricultural lands for external dumps.

Therefore, to decrease mining costs, a technology should be developed to mine blocks in complicated mining and geological conditions without increase of mining costs.

For successful mining of blocks with unfavourable conditions around them, it is reasonable to apply bulkcaving systems without creating significant exposures. Such system is used at Kiruna mine (Sweden) [26-28].

\footnotetext{
Corresponding author: psvknu@gmail.com
} 
The point of the system is in the decreased sublevel height and borehole breaking onto the compressed environment with end drawing due to which the amount of pure undiluted ore mass mined increases [29-32]. However, a considerable number of haulage workings require additional expenses.

When implementing this technology at underground mines of Kryvyi Rih iron ore basin, labour conditions deteriorate and costs for maintaining workings grow because of complicated mining and technical conditions [33-36].

To reduce costs for maintaining main openings, mines implement modern methods of monitoring the rock massif state while disturbing it by underground operations [37-39].

It is also possible to reduce costs on maintaining workings at the expense of breaking ore by deep boreholes onto the compressed environment.

When breaking ore on the compressed environment, the surface of the working is in direct contact with the rock massif and, therefore, the elastic wave from one environment moves into another, into the incident energy. Reaching the fragmentation factor $\left(K_{f}=1.3-\right.$ 1.4), part of the direct energy is used to destroy the rock massif $(75-90 \%)$, and part $(10-25 \%)$ - to compact the material. Displacement of the compressed material in the stope occurs after blasting of the first ring of holes and reaches $3 \mathrm{~m}$ at 4-5 row blasting (or blasting 3 rows of parallel contiguous borehole rounds) and then stops. Material compaction occurs within the $25-30$ m wide area if ore hardness is average and does not exceed $15 \mathrm{~m}$ if rocks are hard [40,41].

Partial drawing of caved ore creates necessary loosening of rock mass before breaking. The number of rows for blasting should be sufficient for the material not to be excessively compacted.

However, application of borehole breaking with the diameter of holes of $105 \mathrm{~mm}$ increases expenses on drilling as the number of borethole rings increases 2-3fold.

\section{Methods}

Based on the conducted critical analysis of works dealing with issues of increasing ore mass extraction in conditions of rock pressure around blocks, the following conclusions can be drawn:

1. The authors suggest increasing the iron content in ore mass at the expense of a mining and concentrating complex or through applying the selective energy saving technology aimed at excluding the concentration process or creation of the compensatory area of various shapes. This will unavoidably result in increased mining costs and, consequently, loss of the world market.

2. Decrease of dilution and increase of extraction without increased mining costs can be reached through replacing the mining system by that without a compensatory area. However, this requires considerable expenses on workings and their maintenance.

Thus, it is necessary to enhance the technology of underground mining of blocks under rock pressure around them to ensure efficient extraction and decreased mining costs.

\section{Results and discussion}

The technique of determining the line of the least resistance and distances between borehole ends should be applied when determining parameters of blasting and drilling operations $[25,36,37,40]$.

Such techniques differ in breaking conditions and estimation criteria. Thus, when mining iron ore deposits, there are applied methods based on placing explosives in the massif depending on stress concentration, rock hardness, qualitative characteristics of explosives, etc $[15,16,37]$.

Analysis of methods of determining parameters of drilling and blasting enables building dependencies of changes in the line of the least resistance on the borehole diameter when using Grammonite 79/21, Fig. 1.

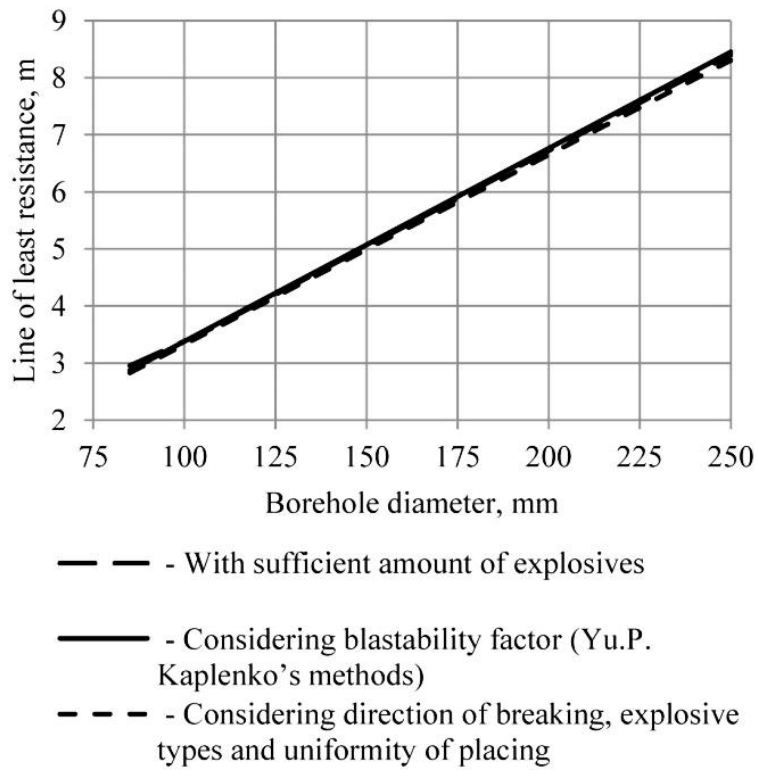

Fig. 1. Dependencies of changes of the line of the least resistance on a borehole diameter when applying various calculating methods.

The graphs in Fig. 1 demonstrate that the analyzed methods for determining the line of the least resistance do not differ significantly from each other and the error does not exceed 20\%. Therefore, the new technique developed by $\mathrm{Yu}$. P. Kaplenko is used for further investigations and calculations. The technique is widely applied at the underground mines of Kryvyi Rih iron ore basin [37].

The line of the least resistance (LLR), the distance between borehole ends and specific consumption of explosives for breaking in terms of ore hardness are determined by the formulas [37]:

$$
\begin{gathered}
W=k_{n} \times C_{o} \times d_{p r}, \mathrm{~m} ; \\
a=m \times W, \mathrm{~m} ; \\
q=\frac{2 \times k_{z} \times U}{a \times W \times \gamma}, \mathrm{kg} / \mathrm{t} .
\end{gathered}
$$


The results of the calculations enable building a dependency of LLR (Fig. 2), the distance between borehole ends (Fig. 3) and specific consumption of explosives for breaking (Fig. 4) on the diameter of the borehole and the ore hardness factor.

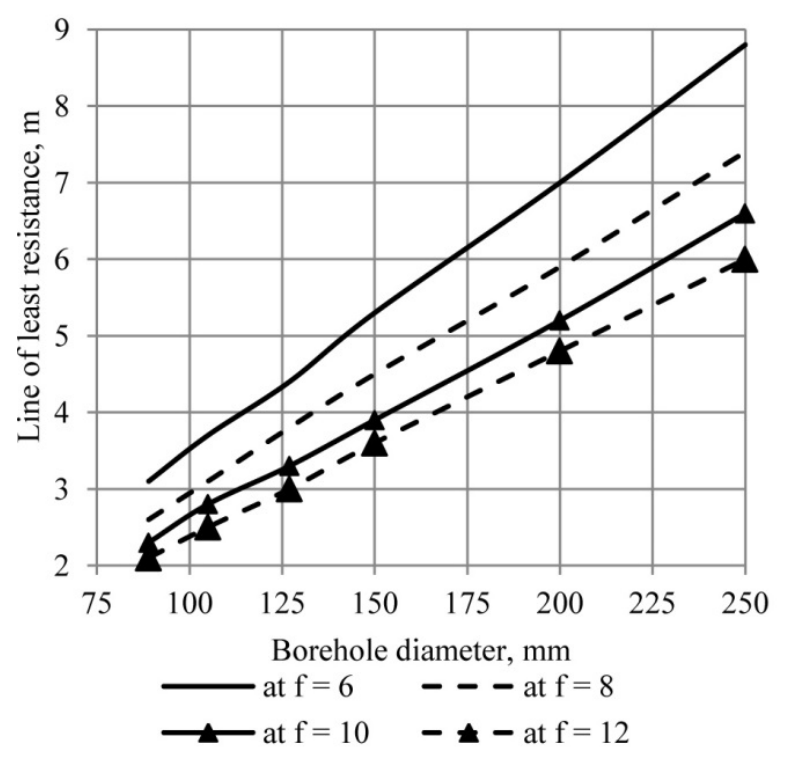

Fig. 2. Dependencies of LLR on the borehole diameter and the hardness factor.

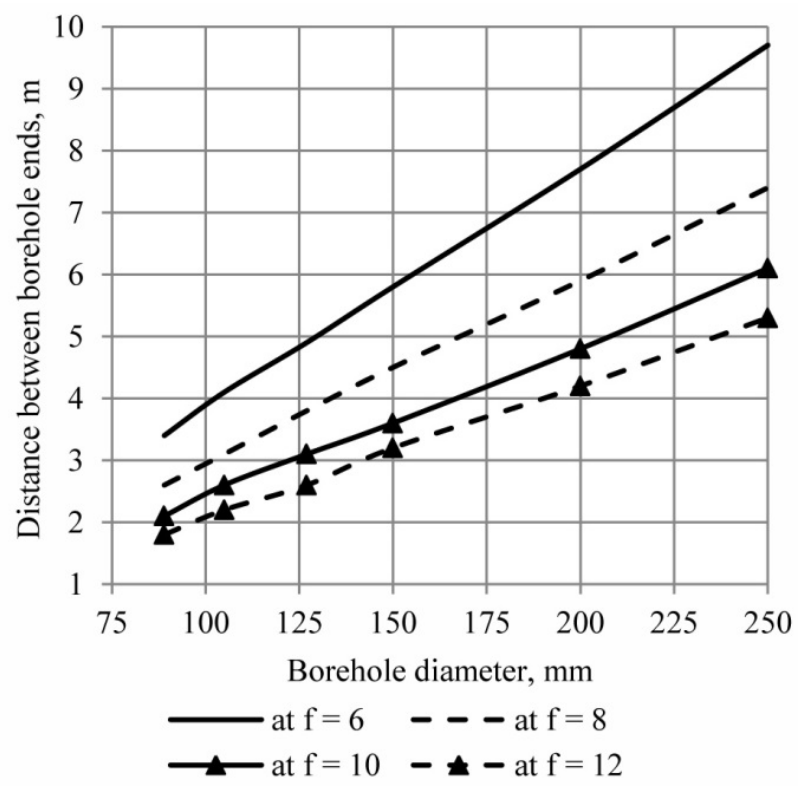

Fig. 3. Dependencies of the distance between borehole ends on the borehole diameter and the ore hardness factor.

The graphs in Fig. 2 demonstrate that with rock hardness of 13 and the borehole diameter from $89 \mathrm{~mm}$ to $250 \mathrm{~mm}$, LLR increases from 2.1 to $6 \mathrm{~m}$ and specific consumption of explosives grows from 0.8 to $0.9 \mathrm{~kg} / \mathrm{t}$ (see Fig. 4).

The graphs in Fig. 3 demonstrate that with the increase of the borehole diameter from 89 to $250 \mathrm{~mm}$ the distance between borehole ends grows from 1.8 to 5.3 at the ore hardness factor of 12 .

Thus, when ore hardness increases, the line of the least resistance, the distance between borehole ends and specific consumption of explosives for breaking grow. This corresponds to the practice of using Grammonite 79/21 when mining iron ores at Kryvyi Rih basin.

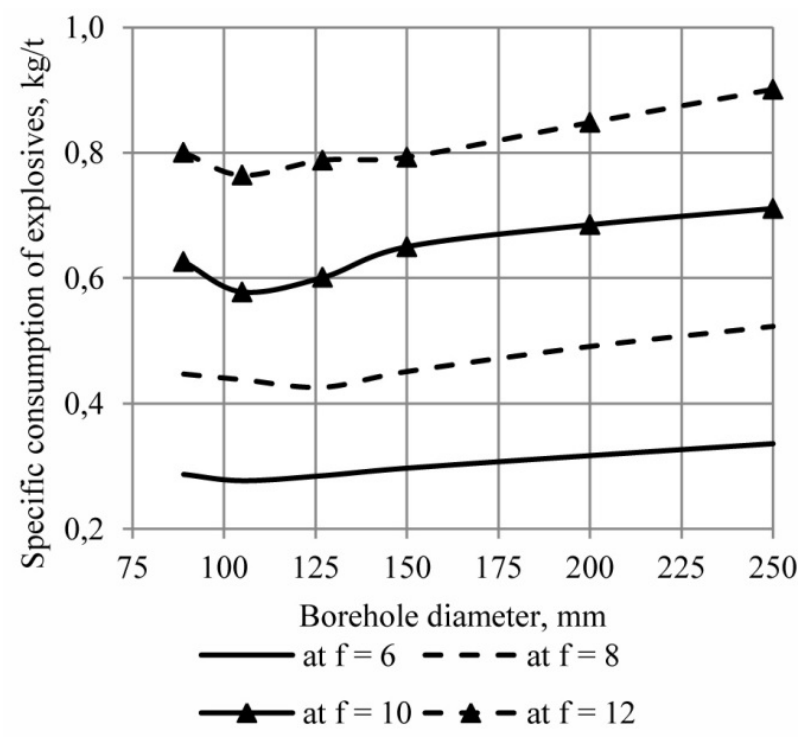

Fig.4. Dependencies of specific consumption of explosives for breaking on the borehole diameter and the ore hardness factor.

According to research data [36], displacement of the compressing material in the stope makes 2-2.5 m after explosion of the first row of boreholes and reaches $3 \mathrm{~m}$ after explosion of 4-5 rows of boreholes (or 3 rows of parallel contiguous boreholes) and then it stops. Compaction occurs in the stope area with the width of $25-30 \mathrm{~m}$ (or $60-80 \mathrm{~m}$ at the average ore hardness and rather thick ore bodies). According to the investigation results, movement of the previously broken ore or caved rock of the adjacent panel on which the ore is broken makes 1-1.2 $\mathrm{m}$ [36].

Displacement of the compressed material depends, first of all, on thickness of the ore layer to be caved. Displacement and compaction occur unevenly depending on the distance from the compressing material; so the farther the distance from the contact separating caved rocks and ore massif is, the smaller displacement and compaction are.

Change of the compressing rock layer from 25 to 15 $\mathrm{m}$ does not produce any noticeable impact on the fragmentation factor of ore and rock on the contact. Major displacement occurs not far $(2-15 \mathrm{~m})$ from the contact. Besides, after the first explosion, compaction and movement of the material occur not far from the contact surface. After subsequent explosions, displacement of the compressing material decreases as forces of internal friction and adhesion that appear in the compacted compressing material obstruct displacement of caved ores and rocks $[36,40]$.

Displacement of the compressed material in the compressed environment depends on the fragmentation factor of ore mass and thickness of the caved compressing material. The volume of the compressing material after movement is calculated by the expression [36]

$$
V_{1}=(L-\Delta t) \times h \times M, \mathrm{~m}^{3},
$$


where $h, L, M$ are height, width, thickness of the mining block, $\mathrm{m} ; \Delta t$ is thickness of the layer when breaking in the compressed environment, $\mathrm{m}$.

Transformations of expression (4) considering volumes of the layers that are broken and overcompacted with the corresponding primary fragmentation factor result in the following expression for determining thickness of the layer when breaking in the compressed environment

$$
\Delta t=\frac{L \times\left(K_{r}-K_{r 1}\right)}{K_{r}}, \mathrm{~m}
$$

where $K_{r}, K_{r 1}$ are the fragmentation factors in the block and the compacted layer respectively

Possible displacement of the compressed layer considering the factor of ore fragmentation in the compressed layer is determined by the formula

$$
l=\frac{\Delta t}{\left(K_{u . r}-1\right)}, \mathrm{m},
$$

where $K_{u, r}$ is the average factor of ore fragmentation after blasting.

It should be noted that in laboratory conditions this formula is only true if width of the broken layer does not exceed $15 \mathrm{~m}$. Calculations by formula (6) enable building dependencies of changes in thickness of the layer onto which ore is compressed on that of the broken ore massif layer, Fig. 5.

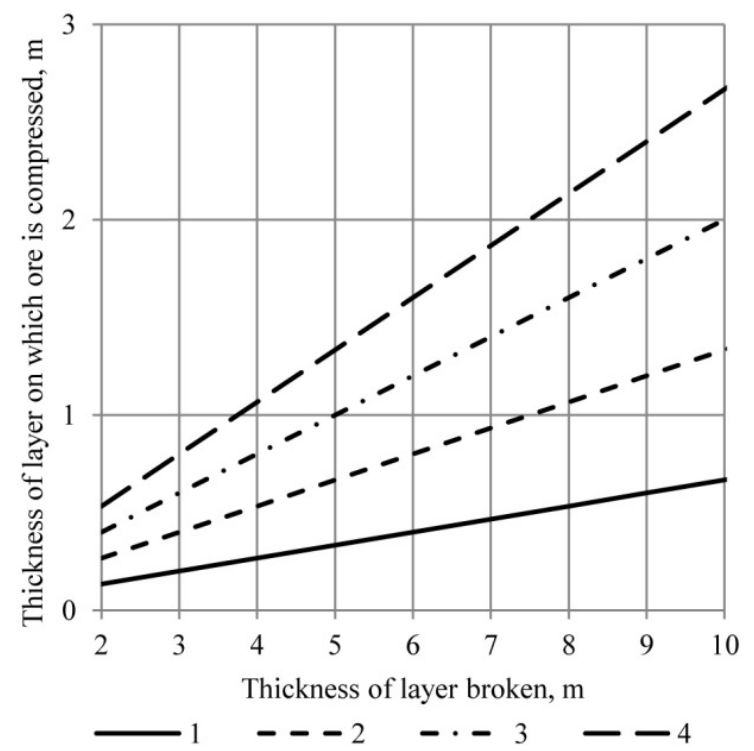

Fig. 5. Dependency of thickness of the ore layer onto which broken ore is compressed on that of the broken ore at the fragmentation factor of caved ore in the over-compacted layer of: $1,2,3,4-1.4,1.3,1.2$ and 1.1 respectively.

The graphs in Fig. 5 demonstrate that increase of the layer of the ore massif to be broken causes increase of the compressing layer width at the sufficient supply of the massif with explosives (i.e. simultaneous firing of 3 rows of parallel contiguous borehole rounds).

Thus, increase of the width of the layer of ore to be broken from 2 to $10 \mathrm{~m}$ causes increase of thickness of the compressing layer from 0.3 to $2.7 \mathrm{~m}$ at the decreased primary fragmentation factor in the over-compacted layer from 1.4 to 1.1 .

The compaction factor mainly depends on the amount of explosives for ore breaking and compaction.

Transformations of equation (5) and its solution with respect to $t_{s t}$ result in the general formula for determining thickness of the ore layer to be broken on caved rocks in the upper part of the block

$$
t_{s t}=\frac{h \times\left(K_{r}-K_{r 1}\right)}{K_{r} \times\left(K_{r}-1\right)} .
$$

Analysis of the expression enables concluding that in practice thickness of the compressed material layer should be determined applying the grapho-analytical method.

Dependencies of thickness of the broken layer on height of the caved layer and the primary fragmentation factor in the over-compacted layer at the primary fragmentation factor of 1.5 are given in Fig. 6 .

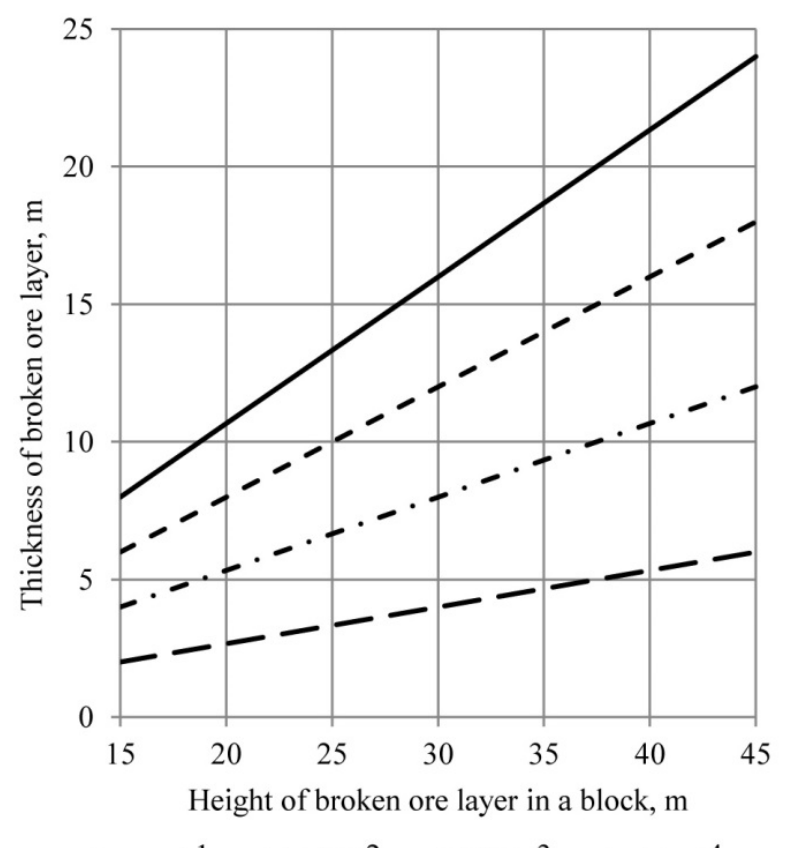

Fig. 6. Dependencies of thickness of the broken layer on height of the caved layer and the primary fragmentation factor in the over-compacted layer at the primary fragmentation factor of the caved layer of 1.5: 1, 2, 3, 4- the primary fragmentation factor in the over-compacted layer is 1.1, 1.2, 1.3 and 1.4 respectively.

Fig. 6 demonstrates that increase of the broken ore thickness (stope height) causes possible increase of thickness of the layer to be caved. Thus, at the necessary factor of primary fragmentation of the over-compacted layer of 1.2, increase of the caved layer height from 15 to $45 \mathrm{~m}$ results in growth of thickness of the caved crown from 6 to $17 \mathrm{~m}$.

When drawing under caved rocks from panels with inclined walls, part of the ore does not enter the area with drawpoints as ore drawing under the caved rocks is conducted at the angle of $60-85^{\circ}$.

It should be noted that expression (7) is true when the block is not impacted by external forces. At underground 
mining of deposits, rock pressure caused by caved rocks located over the caved ore layer changes depending on the depth of mining, Fig. 7.

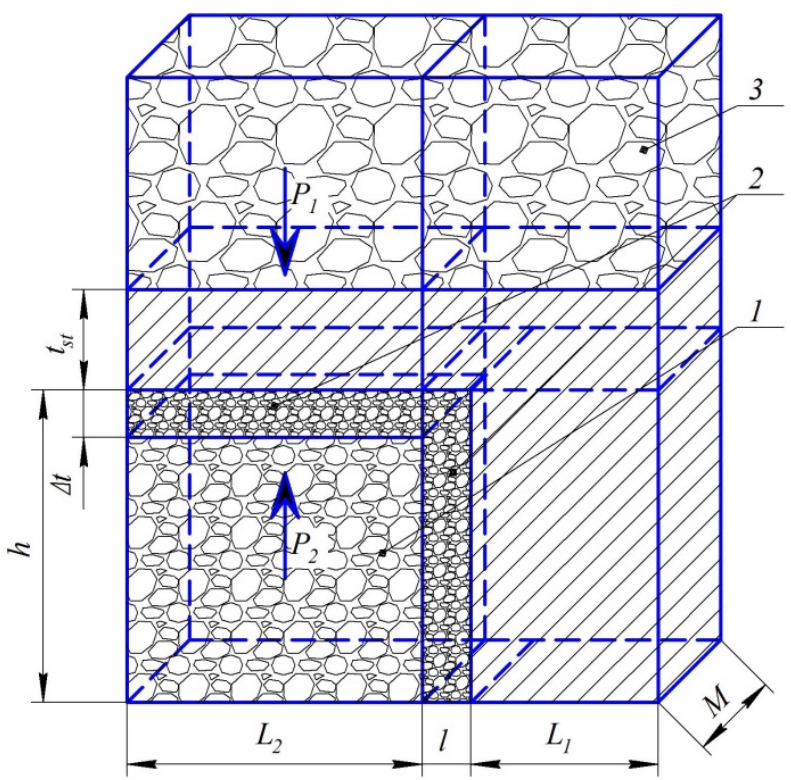

Fig. 7. The chart for determining displacement (movement) of the material to be compressed depending on the caved ore layer considering impacts of external forces.

On this basis, thickness of the layer of ore broken onto caved rocks considering pressure around the mining block is determined by the formula

$$
t_{s t}=\frac{h \times\left(K_{r}-K_{r 1}\right)}{K_{r} \times\left(K_{r}-1\right)} \times K_{\sigma}, \mathrm{m},
$$

where $K_{\sigma}$ is the factor considering rock pressure around the mining block.

The pressure coefficient is determined by relation of rock pressure around the block before and after crown caving and calculated by the formula

$$
K_{\sigma}=\frac{P_{1}^{\prime}}{P_{1}}, \mathrm{~m},
$$

where $P_{1}$ is pressure on the crown before its caving, $\mathrm{MPa} ; \mathrm{P}_{1}^{\prime}$ is pressure on the block after crown caving, $\mathrm{MPa}$.

It should be noted that formula (9) is true when the marginal condition is fulfilled

$$
P_{1} \geq P_{2} \leq P_{1}^{\prime}
$$

Analysis of formula (8) enables concluding that: - when pressure in the upper part of the mining block decreases, after caving the crown, movement of rock mass is observed in both directions (according to the research into breaking ore in the compressed environment) $[21,26,40]$. That is, not only caved ore but also caved rocks will be compacted;

- when pressure in the upper part of the mining block increases, after caving the crown, rock mass will move towards areas with lower rock pressure [36-40].

Harmful influence caused by borehole shooting in the ring can be decreased through out-of-turn borehole firing in the ring.

Quality of ore breaking depends on even distribution of explosives on the whole area of ore to be broken.

The conducted investigation enables suggesting bulk caving of ore and overlying rocks with breaking ore on the compressed environment by deep boreholes of 250 $\mathrm{mm}$ in diameter (Fig. 8).

This option of mining systems implies the following. The deposit is divided into $50-60 \mathrm{~m}$ long blocks along the strike. Vertically, a level is divided into 2-3 sublevels depending on the dip angle of the ore body.

Preparation of a block starts from driving access crosscuts from the haulage entry and drilling ventilation and manway raises on the block sides, Fig. 8. Then, ventilation and manway crosscuts are driven from the ventilation and manway raises. Service and ore discharge raises are driven to the crosscuts from the haulage level.

Two scraper entries are driven from the ventilation and manway crosscuts at the distance of $10 \mathrm{~m}$ from each other. The scraper entries are connected by the ventilation crosscut. $7 \mathrm{~m}$ high drawpoints go out of the scraper entry to the undercut level. Then, at the distance of $10 \mathrm{~m}$ from the scraper level, a drill drift is driven in the footwall. After that, stoping is performed.

Above the scraper level, a slot is formed through driving a $3 \mathrm{~m}$ wide cut raise and then $105 \mathrm{~mm}$ diameter boreholes expand it to the thickness of the ore body. Then, blast holes are drilled for draw points. After that, blast holes and boreholes are fired and part of the broken ore is drawn from the block.

Next, a sublevel is drilled by rings of deep boreholes from the drill drift. Breaking of the panel reserves starts immediately after creating the slot.

The drilling rig NKR-100M is used to drill 2 rings of deep boreholes of $250 \mathrm{~mm}$ in diameter from the drill drift. Then, the boreholes are charged and fired.

The block massif is drilled by drilling rigs with a reamer. First, a pilot hole of $155 \mathrm{~mm}$ in diameter is drilled, and then the hole is reamed to $250 \mathrm{~mm}$. The P150S downhole hammer and the KNSH-155 bit are used for drilling. The reamer K-250 is used to ream the

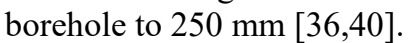

In conformity with the determined parameters of the slot and the ore layer of the massif to be broken, the primary fragmentation factor is 1.35 . To blast the massif, millisecond-delay and delay-action electric detonators are used. After caving the first ore layer and creating the over-compacted layer, $20 \%$ of ore is drawn. Next, $4-8$ rings of deep boreholes are drilled and blasted.

After caving the main part of the reserves, the crown is caved through drilling rings of deep boreholes onto the caved ore compacting the upper and lower layers, Fig. 8.

After the block is broken, ore is drawn and hauled at the receiving level by the scraper winch $30 \mathrm{LS}-2 \mathrm{~S}$ into ore passes and then vibrating feeders ASHL-2 load it into cars VG-10A.

It should be noted that when breaking onto the compressed environment by $105 \mathrm{~mm}$ boreholes, breaking by parallel contiguous boreholes is applied, i.e. 2 rings are drilled in parallel. In case $250 \mathrm{~mm}$ boreholes are applied, distance between their ends is decreased, Fig. 8. 

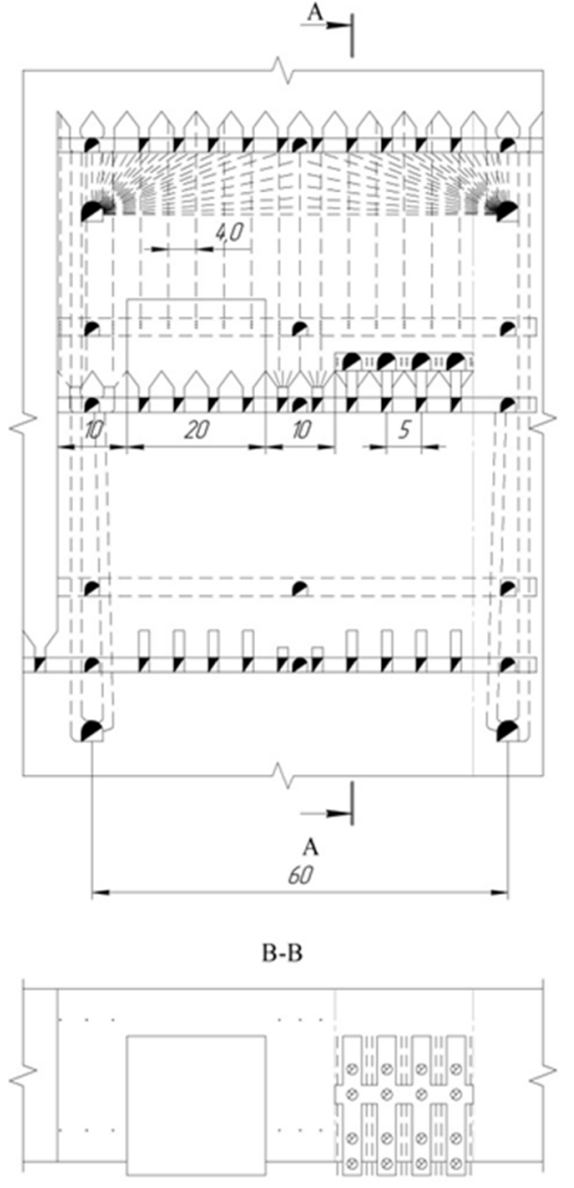

ब

ब

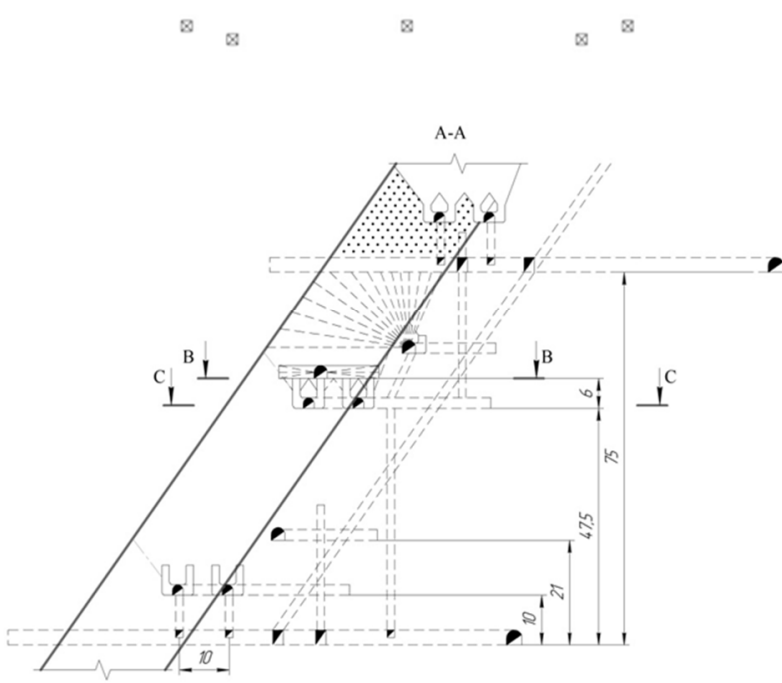

C-C

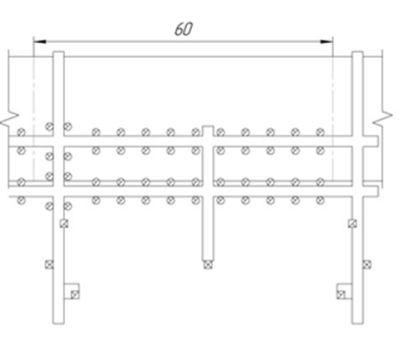

Fig. 8. Drilling by vertical rings of deep boreholes of $250 \mathrm{~mm}$ in diameter onto the compressed environment.
The results of the calculations of blasting and drilling by deep boreholes of $105,250 \mathrm{~mm}$ in diameter with breaking ore onto the compressed environment are given in Table 1.

Table 1. Basic technical and economic indicators when grilling deep boreholes.

\begin{tabular}{|l|c|c|}
\hline \multirow{2}{*}{ Name } & \multicolumn{2}{c|}{$\begin{array}{c}\text { Borehole } \\
\text { diameter: }\end{array}$} \\
\cline { 2 - 3 } & $\mathbf{1 0 5} \mathbf{~ m m}$ & $\mathbf{2 5 0} \mathbf{~ m m}$ \\
\hline Balance reserve of ore in a block, $\mathrm{t}$ & 189000 & 189000 \\
\hline Line of least resistance, $\mathrm{m}$ & 2.8 & 6.6 \\
\hline Distance between borehole ends, $\mathrm{m}$ & 2.6 & 6.1 \\
\hline Total length of boreholes, $\mathrm{m}$ & 23904 & 4310.4 \\
\hline Total explosives, kg & 153737.5 & 124804.4 \\
\hline Ore yield per 1 m of borehole, $\mathrm{t}$ & 7.9 & 43.8 \\
\hline Specific consumption of explosives, kg/t & 0.81 & 0.66 \\
\hline Average piece diameter, m & 0.21 & 0.37 \\
\hline Oversize, \% & 34.3 & 1.1 \\
\hline Labour efficiency at breaking, t/shift & 314.4 & 581.8 \\
\hline Specific labour expenses (drillers), USD & 1.36 & 0.74 \\
\hline $\begin{array}{l}\text { Specific labour expenses (chargers and } \\
\text { shotmen), USD }\end{array}$ & 0.94 & 0.76 \\
\hline Other materials and equipment, USD & 0.34 & 1.18 \\
\hline Drilling and blasting costs, USD/t & 12.40 & 10.6 \\
\hline
\end{tabular}

Advantages:

1. Boreholes of $250 \mathrm{~mm}$ in diameter increase efficiency, depth and accuracy of drilling. One $250 \mathrm{~mm}$ borehole corresponds to $6-7$ bundled boreholes of 105 $\mathrm{mm}$ in diameter.

2. Suitable for use in weak and instable packingaverse ores.

3. No caving of hanging wall rocks

Disadvantages include the following: after drawing first portions of ore, expenses on secondary crushing of ore compacted by blasting increase; application is constrained.

The results of the conducted calculations prove that specific consumption of explosives does not differ significantly. In addition, it should be noted that the increased diameter of boreholes leads to reduction of their length from 23.9 thousand $\mathrm{m}(105 \mathrm{~mm})$ to 4.3 thousand $\mathrm{m}(250 \mathrm{~mm})$.

Ore breaking costs decrease from 12.4 or 12.67 to 10.6 USD/t. Thus, benefits from using boreholes of 250 $\mathrm{mm}$ in diameter for breaking are expected to make 1.8 USD/t. In terms of a mining block, the economic effect will make 340.2 thousand USD. With the annual output of $2.4 \mathrm{mln} \mathrm{t}$, the annual economic effect will make 4.32 mln USD.

The work was supported by the Ministry of Education and Science of Ukraine within the framework of the state scientific topics "Determination of regularities of the stress-strain state of rocks disturbed by workings with the purpose of developing resource-saving ore mining technologies" (State registration No. 0115U003179).

\section{References}

1. V. Kalinichenko, S. Pysmennyi, N. Shvaher, O. Kalinichenko, E3S Web of Conf. 60, 00041 (2018). 
doi:10.1051/e3sconf/20186000041

2. M. Stupnik, V. Kalinichenko, in Annual ScientificTechnical Colletion - Mining of Mineral Deposits 2013, pp. 49-52

3. O. Khomenko, A. Sudakov, Z. Malanchuk, Ye. Malanchuk, Naukovyi Visnyk Natsionalnoho Hirnychoho Universytetu 2, 35-43 (2017)

4. M. Petlovanyi, V. Lozynskyi, S. Zubko, P. Saik, K. Sai, Rudarsko Geolosko Naftni Zbornik 34(1), 8391 (2019). doi:10.17794/rgn.2019.1.8

5. M.I. Stupnik, V.O. Kalinichenko, S.V. Pysmennyi, O.V. Kalinichenko, Naukovyi Visnyk Natsionalnoho Hirnychoho Universytetu 4, 21-27 (2018). doi:10.29202/nvngu/2018-4/4

6. N. Stupnik, V. Kalinichenko, Geomechanical Processes During Underground Mining, in Proceedings of the School of Underground Mining (2012), pp. 15-17

7. O. Kalinichenko, M. Fedko, I. Kushnerov, M. Hryshchenko, E3S Web of Conf. 123, 01015 (2019). doi:10.1051/e3sconf/201912301015

8. N.I. Stupnik, V.A. Kalinichenko, M.B. Fedko, Ye.G. Mirchenko, Naukovyi Visnyk Natsionalnoho Hirnychoho Universytetu 2, 11-16 (2013)

9. N.I. Stupnik, V.A. Kalinichenko, M.B. Fedko, Ye.G. Mirchenko, Naukovyi Visnyk Natsionalnoho Hirnychoho Universytetu 1, 44-48 (2013)

10. M.I. Stupnik, V.O. Kalinichenko, O.V. Kalinichenko, I.O. Muzika, M.B. Fed'ko, S.V. Pismennyi, Metal. and Min. Ind. 7, 377-383 (2015)

11. M. Stupnik, V. Kolosov, V. Kalinichenko, S. Pismennyi, in Progressive Technologies of Coal, Coalbed Methane, and Ores Mining (2014), pp. 2530. doi:10.1201/b17547

12. O. Khomenko, M. Kononenko, M. Petlyovanyy, in Progressive Technologies of Coal, Coalbed Methane, and Ores Mining (2014), pp. 241-245. doi:10.1201/b17547-43

13. M. Petlovanyi, V. Lozynskyi, P. Saik, K. Sai, E3S Web of Conf. 123, 01019 (2019). doi:10.1051/e3sconf/201912301019

14. Z.R. Malanchuk, V.S. Moshynskyi, V.Ya. Korniienko, Ye.Z. Malanchuk, V.H. Lozynskyi, Naukovyi Visnyk Natsionalnoho Hirnychoho Universytetu 6, 11-18 (2019). doi:10.29202/nvngu/2019-6/2

15. V. Serhiienko, E3S Web of Conf. 109, 00084 (2019). doi:10.1051/e3sconf/201910900084

16. N. Morkun, T. Oliinyk, I. Kasatkina, O. Rytsko, E3S Web of Conf. 123, 01038 (2019). doi:10.1051/e3sconf/201912301038

17. V. Tron, O. Tsokurenko, D. Paraniuk, I. Haponenko, E3S Web of Conf. 123, 01037 (2019). doi:10.1051/e3sconf/201912301037

18. V. Morkun, N. Morkun, A. Pikilnyak, Metal. and Min. Ind. 6(2), 36-42 (2014)
19. V. Golik, V. Komashchenko, V. Morkun, Metal. and Min. Ind. 7(4), 321-324 (2015)

20. V. Golik, V. Komashchenko, V. Morkun, O. Burdzieva, Metal. and Min. Ind. 7(6), 591-594 (2015)

21. A. Kupin, D. Kuznetsov, I. Muzyka et al, East.European J. of Enterprise Tech. 4, 2(94), 71-79 (2018)

22. D.V. Brovko, V.V. Khvorost, V.Yu. Tyshchenko, Naukovyi Visnyk Natsionalnoho Hirnychoho Universytetu 4, 66-71 (2018). doi:10.29202/nvngu/2018-4/14

23. V. Morkun, N. Morkun, A. Pikilnyak, Metal. and Min. Ind. 6(2), 43-48 (2014)

24. O. Khomenko, M. Kononenko, M. Petlovanyi, in New Developments in Mining Engineering 2015 (2015), pp. 265-269. doi:10.1201/b19901-47

25. V. Lozynskyi, P. Saik, M. Petlovanyi, K. Sai, Z. Malanchuk, Intern. J. of Eng. Res. in Africa 35 (2018). doi:10.4028/www.scientific.net/jera.35.77

26. S. Dineva, M. Boskovic, in Proceedings of the Eighth International Conference on Deep and High Stress Mining, ed. by J. Wesseloo (Australian Centre for Geomechanics, 2017), pp. 125-139

27. Y. Biruk, H. Mwagalanyi, Master's thesis. Department of Civil, Environmental and Natural Resources Engineering 74 (2010)

28. K. Rysbekov, D. Huayang, T. Kalybekov, M. Sandybekov, K. Idrissov, Y. Zhakypbek, G. Bakhmagambetova, Min. of Miner. Dep. J. 13, 3, 40-48 (2019). doi:10.33271/mining13.03.040

29. O. Khomenko, M. Kononenko, I. Kovalenko, D. Astafiev, E3S Web of Conf. 60, 00009 (2018). doi:10.1051/e3sconf/20186000009

30. M. Petlovanyi, O. Kuzmenko, V. Lozynskyi, V. Popovych, K. Sai, P. Saik, Min. of Miner. Dep. J. 13, 1, 24-38 (2019). doi:10.33271/mining13.01.024

31. T. Kalybekov, M. Sandibekov, K. Rysbekov, Y. Zhakypbek, E3S Web of Conf. 123, 01004 (2019). doi:10.1051/e3sconf/201912301004

32. B.M. Andreev, D.V. Brovko, V.V. Khvorost, Metal. and Min. Ind. 12, 378-382 (2015)

33. V. Dengub, V. Shapovalov, M. Hudyk, Metal. and Min. Ind. 5, 67-71 (2015)

34. V. Morkun, N. Morkun, V. Tron, Metal. and Min. Ind. 7(8), 18-21 (2015)

35. V. Tron, O. Tsokurenko, D. Paraniuk, I. Haponenko, E3S Web of Conf. 123, 01037 (2019). doi:10.1051/e3sconf/201912301037

36. V.R. Imenitov, Protsessy podzemnykh gornykh rabot pri razrabotke rudnykh mestorozhdeniy (Underground mining processes in the development of ore deposits). (Nedra, Moskva, 1984)

37. Yu.P. Kaplenko, V.A. Kolosov, Instruktivnometodicheskiye ukazaniya po vyboru parametrov burovzryvnykh rabot (BVR) pri podzemnoy dobyche rud. CH. I. Vybor parametrov BVR pri provedenii 
vyrabotok (Guidance on the selection of parameters for drilling and blasting operations (BWR) in underground ore mining. Choice of BVR parameters during mine workings) (Mineral, Krivoy Rog, 2007)

38. R.O. Dychkovskyi, V.H. Lozynskyi, P.B. Saik, M.V. Petlovanyi, Y.Z. Malanchuk, Z.R. Malanchuk, Archives of Civil and Mechanical Engineering 18(4), 1183-1197 (2018). doi:10.1016/j.acme.2018.01.012

39. V. Morkun, N. Morkun, V. Tron, Metal. and Min. Ind. 7(10), 6-9 (2015)

40. M.I. Agoshkov, S.S. Borisov, V.A. Boyarskiy, Razrabotka rudnykh $i$ nerudnykh mestorozhdeniy (Development of ore and non-metallic deposits). (Nedra, Moskva, 1983)

41. V. Morkun, N. Morkun, V. Tron, S. Hryshchenko, O. Serdiuk, I. Dotsenko, Archives of Acoustics 44(1), 161-167 (2019) 